\title{
ORgANizATIONAL CULTURE TYPE IN TURKISH UNIVERSITIES USING OCAI: PERCEPTIONS OF STUDENTS
}

\author{
AYSUN CALISKAN \\ Vrije Universiteit Brussel, \\ Pleinlaan 21050 Brussel \\ E-mail address: aysun.calikan@vub.be \\ ORCID number: 0000-0002-2811-286X \\ CHANG ZHU \\ Vrije Universiteit Brussel, \\ Pleinlaan 21050 Brussel \\ E-mail address: chang.zhu@vub.be \\ ORCID number: 0000-0002-0057-275X
}

\begin{abstract}
Aim. The aim of this research is to identify student perceptions of the current organizational culture type in four flagship Turkish public universities. Its further goal after this diagnosis was to help the researchers and policy makers to deeply understand the actual situations and make recommendations for organizational culture change and educational innovations. Methods. We applied a mixed-method approach to collect data. The quantitative method consisted of 964 applications of the instrument of OCAI to bachelor students. The qualitative method included 19 semi-structured interviews to follow up and verify the results from the survey to have a deeper insight into Turkish HEIs.

Results. The variety of findings through survey and interviews revealed and validated that the dominant culture type of Turkish universities regarding students is hierarchy followed by market culture. It is probable that the national cultural structure of the Turkish society is a result of this finding. It appears that Turkey has a hierarchical workplace attributing control, order, authority, and smooth functioning.

Conclusions. Based on student perceptions, this study can provide policy makers, academic leaders, academic staff and employees in administrative units with a broader knowledge of the current organizational culture type in universities in Turkey, and identify the strengths and weaknesses of organizational culture in universities and to improve the quality through making innovations.
\end{abstract}

Key words: organizational culture type, Turkish universities, OCAI, students' perceptions, mixed method, hierarchy culture 


\section{INTRODUCTION}

U nderstanding organizational culture is of fundamental importance in examining what goes on in organizations, how to run them and how to improve them (Schein, 2010). There have been many definitions provided for organizational culture. Organizational culture can be defined as getting things done (Deal \& Kennedy, 1982), symbols, values, procedures, ceremonies, approaches characterising an organization (Cameron \& Quinn, 2011) and the glue that brings people together within an organization (Beyer \& Nino, 2001). Edgar Schein (2010), one of the most exceptional theorists of organizational culture, defines it as the complex pattern in which the members create, find and figure out concrete ways to cope with problems. Hence, these issues should be instructed to new members for better understanding of the new environment. In this manner, culture is passed on to the new eras of gathering individuals by means of the socialisation procedure through members' jargon such as stories, myths, rituals, norms, habits, nonverbal signs and symbols (Leland, 2002).

Researchers across different disciplines have recognised the critical role played by organizational culture and connected it to the effectiveness and central processes of the organization, especially in the last decades of the 20th century (Kezar \& Eckel, 2002). Some studies have associated "strength" and "congruence" with the organization's effectiveness (Ostroff, Kinicki, Tamkins, 2003; Wilderom, Glunk \& Maslowski, 2000) while others indicate "the type of organizational culture" as a key element (Cameron \& Freeman, 1991; Denison \& Mishra, 1995; Kotter \& Heskett, 1992; Ostroff et al., 2003; Wilkins \& Ouchi, 1983). Kim Cameron and Robert Quinn (2011) the most outstanding scholars in this field, believe that organizational culture type reveals the success of the organization through the organization's compatibility with the environment and long-term goals, style and inclinations. Against this background, one can argue that there is a causal relationship between the culture type of organization and the level of performance and effectiveness (Cameron \& Freeman, 1991).

Several models have been developed to describe various indicators of the culture in assessing the organizational culture and effectiveness. Charles Handy (1993), who created a four-type culture model based on organizational structure, argued that each culture type is congruent with different environment and personality, in other words, what works well in one organization may not work in another or an employee who is successful in one organization may not do well in another. Furthermore, as Fons Trompenaars (1993), Terrence Deal and Allan Kennedy (1982), K. Cameron and R. Quinn (2011) have claimed that a combination of culture types may be present in organizations. Karen Cacciattolo (2014) has argued that in real-life organizations, more than one culture type may exist, and sub-cultures may overlap or conflict with each other.

In a university, all stakeholders including trustees, administrators, faculty members, campus community members, students, and society should come together to shape the effectiveness of the university (Gayle, Tewaire \& White, 2003). In terms of students, Frances M. Hill (1995) supports that students are 
the direct recipients of the service provided at universities and the key indicators of institutional effectiveness is student academic development (Dill, 2014) and organizational culture (Deem, DeLotell \& Kelly, 2015; Ramachandran, Chong \& Ismail, 2011; Smart, Kuh \& Tierney, 1997). As a response to the attention given to the students in literature and to fill the gap regarding the perceptions of students on organizational culture type in Turkish universities, the present study aims to provide a detailed analysis of the student perceptions of organizational culture type in Turkish universities. The design of the study allows for commentary on the advantage of both quantitative and qualitative methods. For the quantitative phase, the Cameron and Quinn model has been chosen and the instrument OCAI (Organizational Culture Assessment Instrument) has been used as a survey tool because it is the most used, actual and useful framework with its central database in defining organizational culture types. It is validated in a lot of research both in Turkey (Aç1kgöz, 2006; Beytekin, Yalçınkaya, Doğan \& Karakoç, 2010; Erdem, 2007; Erdem et al., 2010; Kurgun \& Bağıran, 2013) and in the world (Cameron \& Quinn, 2011; Denison, 1990; Deshpande \& Farley, 2004; Howard, 1998; Linnenluecke \& Griffiths, 2010; Ralston, Tong, Terpstra, Wang \& Egri, 2006). For the qualitative phase, a semi-structured interview was conducted to penetrate deeply into the perceptions and opinions of the students and go beyond what can be uncovered through questionnaires. The importance and originality of this study derive from two primary reasons.

1. To undertake a combination of quantitative and qualitative approaches using OCAI.

2. To ascertain the perceptions of Turkish university students.

\section{ORGANIZATIONAL CULTURE AT UNIVERSITY LEVEL}

Over the past two decades, universities have been under pressure to adapt to political, cultural, technological and social changes. One reason for this relentless and cumulative pressure is the unprecedented growth and technological forces accompanying the global economy, complexity and socio-political competitiveness of the changing environment (Cohen, 2001). Another reason is rapidly increasing globalisation and international competition. The establishment of common markets and the mobility of students and academic staff can result in academic reform (Sporn, 1999). The key reason what Aleksander Kobylarek (2017) constitutes is the technocratic order. He briefly explains the idea that the traditional way of universities is replaced by the economic demands ceasing the university to be a place just for the elites.

Scholars have focused on the university culture to be able to create effective, productive and innovative organizations in this competitive world. A. Kobylarek (2017) investigated that the successful university culture should regard the changing world of science, culture and communication technologies that surrounds it. In addition, as a living organism, it is important that the universi- 
ties must evolve to create unique chemistry to hold the stakeholders together (Simplicio, 2012). Besides, university culture is used as a descriptive tool to link the improvement and success (Beytekin et al., 2010). At the university level, William Tierney (1988) claimed that organizational culture in universities leads to understanding the interconnected web between different actors and the structure, rules and regulations.

The culture, at the university level, tended to use to refer to the values, attitudes, and beliefs shared by the university stakeholders (i.e., managers, faculty, students, board members and support staff) at a certain time and place which naturalised their behaviour. People are guided by the values, beliefs and assumptions. It is an intellectual device which comes about through stories, corporate language and norms (Cameron \& Freeman, 1991; Kezar \& Eckel, 2002; Köse, 2017; Lamond, 2003; Sporn, 1999).

Universities are people-oriented organizations in which the internal (academic staff, students) and external (local community, pollical activists, quality assurance agencies, press) stakeholders are involved. It becomes obligatory to create different services and standards for each task. In addition, the academic and administrative staff have different interests. Thus, it gets complicated to establish coordination for governing and managing the university. due to the involvement and different interests of academic and administrative staff. universities are exposed to their environment. Moreover, changes in external conditions (political, economic, social, technological) influence the situation of universities which oblige them to a strategic activity planning (Bartell, 2003).

Unlike most professional organizations, universities are complex organizations with certain dominant features that respond to different imperatives in the environment (Deal \& Kennedy, 1982). University culture can be assessed in many ways. For example, Tony Becher (1989) studied academic tribes and cultures and developed a theoretical framework for four different natures of knowledge (cumulative, holistic, purposive, functioning). To him, globalization affected the universities. Nancy Fjortoft and John C. Smart (1994) differentiate organizational culture in terms of dynamism and externalism, meaning that universities prefer dynamic or stable culture and external or internal orientation. William Ouchi (1980) advocated a threefold typology of organizational culture type - clans, bureaucracies, markets. These culture types served as an alternative "governance modes". They represent different and exclusive mechanisms by which individual behavior can be controlled or influenced.

Sporn (1999) studied organizational culture in terms of two aspects - strong and weak. While strong university culture refers to shared values and strong norms, weak university culture is characterized by disagreement about the main values and absence of norms. According to E. Schein (2010), the strength of culture is determined by the length of the group's shared experience and homogeneity of group members. Cameron and Quinn (2011) investigated the underlying cultural dynamics that exist in organizations. They notified that 
the type of organizational culture (clan, adhocracy, market. hierarchy) is more important for the organizational effectiveness rather than organizational congruence and strength.

So, the most reasonable action to be taken for shaping the complex culture of universities is to understand that it has a holistic entity with its internal and external stakeholders (Vasyakin, Ivleva, Pozharskaya \& Shcherbakova, 2016).

\section{CAMERON AND QUINN'S MODEL OF ORGANIZATIONAL CULTURE}

The organizational culture serves as a guide to adapt to environmental and internal circumstances, helps to solve problems, and even as a tool to improve management, enhance the functioning and develop strategies (Lacatus, 2013), so many scholars (Deal \& Kennedy, 1982; Handy, 1993; Hofstede, 2001; Schein, 2010) have proposed some survey models to analyse and measure it. Among these, Cameron and Quinn's "Competing Values Framework" model (CVF) is a formidable and valid one to explain the organizational culture. CVF is a matrix of four competing values that are in accordance with four types of organizational culture. In their pioneering book of Diagnosing and Changing Organizational Culture, K. Cameron and R. Quinn (2011), specify that CVF is effective in determining the major approaches to organizational design, stages of life cycle development, organizational quality, theories of effectiveness, leadership roles and roles of human resource managers, and management skills. CVF has two major dimensions and four main clusters (see Figure 1). These dimensions form four quadrants, each representing a culture type - clan, adhocracy, market, and hierarchy.

While the horizontal dimension refers to cultures with an internal focus, integration, short term orientation and smoothing activities on the left and to cultures with an emphasis on external positioning, long-term orientation, and achievement-oriented activities on the right, the vertical dimension moves from the cultures characterized by flexibility, discretion, individuality, and spontaneity at the top and cultures

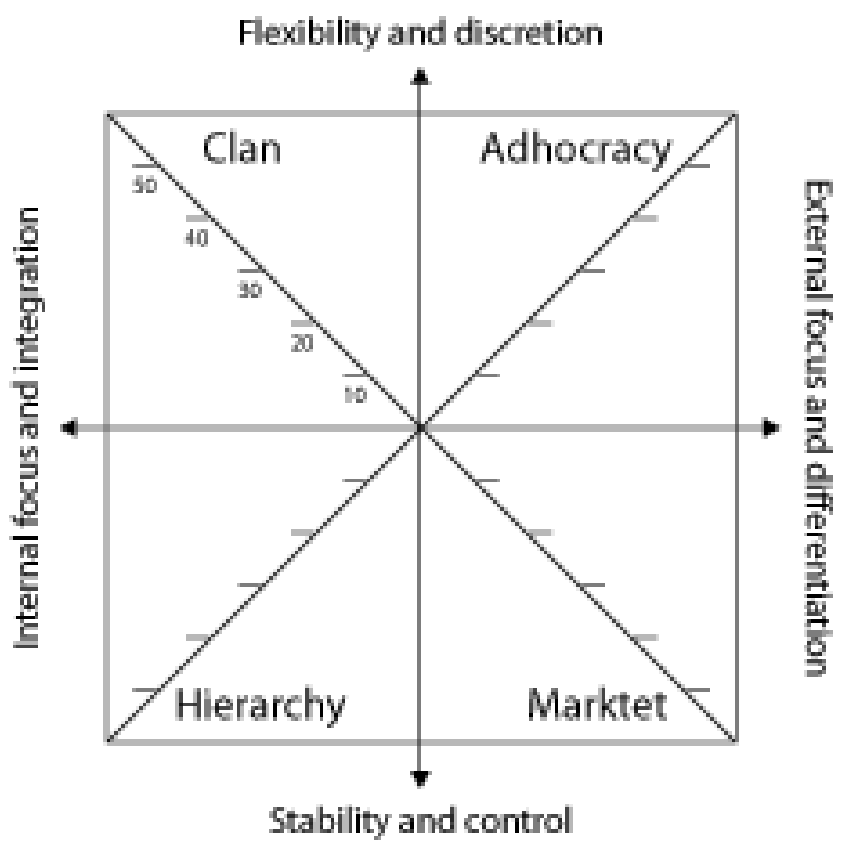

Figure 1.

The Competing Values Framework

Source: K. Cameron and R. Quinn, 2011 
characterized by stability, control, and predictability at the bottom. The models seem to cover four different scopes; however, they can be tightly interconnected. The four culture types in the framework define the hidden values of people, assumptions, orientations, programs, and policies of an organization (Beytekin et al., 2010).

Hierarchy Culture can be simply identified through structured space. In a formalised place, there are fixed rules and policies for holding people together. Market culture can be characterised by a result-oriented place. It focuses on the competitiveness both between the organization and its market competitors and between the employees. The organization is united by achievement and winning. Clan Culture is directly opposite the set of values in hierarchy and market culture types. It is a family-like culture which emphasises collaboration. The clan culture stands for a friend-like environment. It stresses collaboration and communication. The organization is rooted in commitment to family values. Adhocracy culture develops a set of assumptions that differ from those of the other three culture types. It is assumed that it is more dynamic and innovative which gives rise to success and new resources. So, particular emphasis is put on vision, imagination, and creativity. It also allows individual participation and flexibility to accomplish tasks. This contrasts with hierarchy culture which relies on a set of defined rules and stability (Cameron \& Quinn, 2011). They also developed Organizational Culture Assessment Instrument (OCAI) based on the CVF framework.

\section{TURKISH HIGHER EDUCATION CONTEXT}

In Turkey, there are 183 universities, consisting of 116 public universities and 67 non-profit foundation universities. Turkish higher education has a highly centralised governance structure that has been led by the Council of Higher Education (COHE) since 1981. COHE is responsible for planning, coordinating and making policies for higher education. Universities have autonomy under the umbrella of $\mathrm{COHE}$, which means university leaders set the objectives, the missions and visions in line with national higher education policy (YÖK, 2017).

Like all the universities in the world, Turkish universities serve a platform for internal relations between administrative staff, academic staff, students, employees, and external relations with government, alumni, parents, social organizations, and also other universities. This diversity of the relations urges researchers to study the university's organizational culture. So, numerous researches on Turkish university culture have been naturally warranted regarding academic staff members or managers (Beytekin et al., 2010; Erdem, 2007; İplikçi \& Topsakal, 2014; İra, 2011; Köse, 2017; Kurt, 2015; Murat \& Açıkgöz, 2007; Özcan, Karataş, Çağlar \& Polat, 2014; Özdevecioğlu \& Akın, 2013; Öztürk, Şaklak \& Yılmazer, 2010; Yaman \& Ruçlar, 2014). 
However, only a limited number of studies have been identified in organizational culture regarding students in Turkey. For example, Ferda Erdem and Janset Ö. İşbaş1 (2001) conducted an empirical study on the students of Akdeniz University regarding the importance of organizational culture. They found out that organizational structure and educational processes should be improved.

In accordance with that study, Kürşat Y1lmaz and Ebru Oğuz (2005) investigated the perceptions of students of Ankara University Faculty of Educational Sciences regarding organizational culture. The students expressed that there were some problems in the faculty physical structure, communication, and management.

In addition, Kemal Köksal (2007) determined the perceptions of students in Balıkesir University about their faculty culture. The results show that the students have positive perceptions of power distance and communication between peers while they have negative perceptions of physical structure, teacher's attitude and belonging.

In a subsequent study investigating the perceptions of students about faculty culture and the quality of university life, Türkan Argon and Meryem Kösterelioğlu (2009) reached the conclusion that the students' perception about faculty culture is positive.

In another study, Fatih Bektaş (2010) examined the effects of organizational image on culture of the organization according to perceptions of preservice teachers in Atatürk University. The results demonstrated that the factors of organizational image predicted $57 \%$ of the culture of organization as positive.

More specifically, Mustafa Kesen and Bülent Akyüz (2015) measured the relationship between perceived stress levels of university students and university organizational culture perceptions in Bayburt University. They concluded that perceived stress level and university organizational culture are affected by different demographic variables.

Together, these studies indicate the importance of organizational culture, the problems in organizational culture, the quality of university culture and the image of universities just in one university. However, such studies remain narrow in focusing on the entire organization as the unit of analysis, different sub-unit cultures or the dominant types of the entire or sub-unit cultures.

In this research study, we are interested primarily in identifying the overall and the sub-dimensional organizational culture profile such as the management style, strategic emphasis, cultural strength, leadership, success criteria and basic values of the Turkish universities using OCAI. The target level of cultural analysis is the students because they are the direct recipients of the performance and activities. So, their perceptions provide a deeper understanding of the key points that need to be changed. 


\section{RESEARCH OBJECTIVES AND RESEARCH QUESTIONS}

This study aimed at identifying student perceptions of current organizational culture type in four flagship Turkish public universities. The following are the research questions:

- RQ1: How do students of teacher training programs perceive current organizational profile at public universities in Turkey using OCAI?

- RQ2: How do students of teacher training programs perceive current organizational profile per dimension at public universities in Turkey using OCAI?

\section{METHODOLOGY}

To gain a greater insight into the perceptions of students towards the organizational culture type in their universities, we applied a mixed-method approach, which employs two layers of methods to collect data. In this study, the quantitative method consisted of the application of a survey of the questionnaire to the bachelor students to identify the organizational culture type. The qualitative method included semi-structured interviews to follow up and verify the results from the survey not to create a new data set. This study aimed to verify and increase the credibility and validity of the data by combining elements from a survey questionnaire and a semi-structured interview. As Jill Collis and Roger Hussey (2009) argue that triangulation methodology provides the researchers with a broad and approving consideration of the research problem. Alan Bryman (2016) implies that it uses two or more research methods to cross check the results to counterbalance the weaknesses of each finding.

\section{QUANTITATIVE METHOD}

\section{Instrument}

In our quantitative study, we used Organizational Culture Assessment Instrument (OCAI) developed by Quinn and Cameron based on the competing values framework to identify the demographic details, investigate the perceptions of students in Turkish universities and determine the organizational culture type in Turkish universities in a limited time with a low cost. There are 24 items in the scale consisting of six key dimensions to rate the type of organization. These six dimensions are: dominant characteristics, organizational leadership, and management of employees, organizational glue, strategic emphases, and criteria for success. In each dimension, there are four alternatives (A, B, C, D) referring to clan, adhocracy, market and hierarchy culture types respectively. Respondents are expected to divide 100 points among these four alternatives of each cultural dimension regarding their current or preferred organizational culture type. 
There are two versions of the instrument, Likert scales, and ipsative scales. Both versions are compatible with the Organizational Culture Assessment Instrument (Quinn \& Spreitzer, 1991). In the Likert version, participants are allowed to score all elements equally, whereas in the ipsative, they are forced to contrast the elements.

\section{Ipsative measurement}

In the present study, we have consciously selected the ipsative alternative which allows participants to allocate 100 points among four items of each cultural dimension for the current cultural type of their universities.

Ipsative data scales let the participants rank a set of values or prefer one value rather than another in a forced way (Meglino \& Ravlin, 1998). Thus, respondents must compare the elements by giving a fixed number instead of choosing the most desired option as in the normative scores such as Likert scales (Eijnatten et al., 2015). Each quadrant (clan, adhocracy, market, hierarchy) in OCAI is interdependent (Quinn \& Spreitzer, 1991) due to the holistic view of the organizational culture (Lamond, 2003). These quadrants exist together in organizations in a balance with some values more dominant than the others. So, they are interdependent (Quinn \& Spreitzer, 1991).

In ipsative measurement, correlating cases and $Q$ factor analysis are possible to determine the profile types and receive relevant results (Johnson et al, 1988). However, as Quinn and Spreitzer (1991) stated, correlations, factor analysis and regression are not appropriate in ipsative scales.

\section{Sample}

The target population consisted of undergraduate teacher training program students in 4 public universities in Turkey. We aimed to include four public universities which are in the ranking list of the Entrepreneurial and Innovative University Index 2015 prepared by TUBITAK (Scientific and Technological Research Council of Turkey). Out of 50 universities, the universities were selected because each was on the different percentile on the list and got different points. To ensure anonymity, we coded universities as: University 1, University 2, University 3, University 4 and we calculated the percentile of the universities and wrote an approximate percentile. Universities' percentiles are as follows: University 1: between 50-70\%. University 2: between $30-50 \%$, University 3: between 10-30\%, University 4: first 10\%. Hence, it can be assured that the OC types of these four universities represent the general academic culture in Turkey. A total of 1038 undergraduate students from second-year student to final-year student participated in the survey and the valid questionnaires were 964 . Table 1 depicts the distribution of students by independent variables. 
Journal of Education Culture and Society No. 2_2019

Table 1. Distribution of students by independent variables.

\begin{tabular}{lcc}
\hline \multicolumn{1}{c}{ Variables } & $N$ (Participants) & \% (Percentage) \\
\hline University & 243 & 25 \\
U1 & 253 & 26 \\
U2 & 237 & 25 \\
U3 & 231 & 24 \\
U4 & & \\
Gender & 741 & 77 \\
Female & 223 & 23 \\
Male & & \\
Age & 207 & 21 \\
19 & 287 & 30 \\
20 & 217 & 23 \\
21 & 253 & 26 \\
22 and more & & 31 \\
Year & 300 & 37 \\
Second & 357 & 32 \\
Third & 307 & \\
Fourth & & 53 \\
Discipline & 508 & 31 \\
Soft Science & 298 & 16 \\
Hard Science & 158 & $\mathbf{1 0 0}$ \\
Foreign Language & 964 & \\
Total & & \\
\hline
\end{tabular}

\section{Data Collection}

Prior to data collection, we obtained the data collection ethical approval from METU Ethics Committee. Once permission was granted, students were given the opportunity to participate in the research according to participants' availability.

This part of data was collected through a self-administered paper-and-pencil survey that took approximately 25-30 minutes to complete. The survey was administered by teachers (who agreed to support this research) and the researcher during their course sessions or group activities.

\section{Data analysis}

In our study, we used the alternative analysis method provided by Frans M. van Eijnatten, Andries van der Ark and Sjena Holloway (2015) through the R-software package and SPSS version 25.0. According to them, in ipsative data, basic statistical analyses cause two main biased problems. The first one is that the values of covariances and correlations cannot be used to determine the inner structure of the data. The second is that normative measurement cannot be used to compare between organizations or participants. So, they suggested alternative parametric statistical methods to analyse the ipsative measures of 
OCAI: the closed geometric mean, the non-parametric bootstrap test. These methods are described as follows respectively:

1. Geometric mean: It is regarded as the natural center of ipsative data (Aitchison, 1986) which can reduce the effect of very high and low values. It is generally used for comparing different items and reaching a single figure for multiple items which might divert the mean if the arithmetic mean was calculated (Amintoosi \& Kanhere, 2013).

2. Nonparametric bootstrap test: This test has demonstrated how to construct $95 \%$ confidence intervals as the following: (i) exclude nonparametric data, (ii) calculate the collective dimensional profile (CDP) for each bootstrap with the closed geometric means (iii) calculate the Aitchison Distance for each bootstrap, (iv) delete the CDP profiles regarding the 5\% largest Aitchison Distance (v) determine the lowest and highest values for each component of the remaining 95\% of the bootstrap mean (Eijnattan et al., 2015).

These alternative approaches for intra-individual analysis and ipsative data analysis fulfill the main statistical requirements which are scale invariance, permutation invariance, sub-compositional coherence. This approach is especially needed since the instrument OCAI is very common in organizations. In this study, it has computed actual organizational culture profiles in the universities (Eijnattan et al., 2015). However, it is argued that ipsative scales only measure relative rather than absolute values which compare intra-organizations not inter organizations (Cattell, 1944; Eijnattan et al., 2015; Hicks, 1970). Eijnatten et al. (2015) argue that the most featured statistical approaches cannot be clear in this limitation. They also add that in case of OCAI, ratios between the different culture types can be interpreted significantly. Thereby, we can discuss our results to compare relative values in universities. We could not make factor analysis and normative analysis because ipsative data is robust.

Before starting to analyse, missing values and values without a sum of 100 points were identified and 74 (\%7) cases were excluded from the analysis. The closed part-wise geometric mean and $95 \%$ confidence intervals (CIs) of the individual dimensions by universities were calculated (see Table 3 and Table 4).

\section{Qualitative method}

Although there are some limitations in ipsative scales, we believe that we have reduced bias relatively by conducting interviews which gave us the chance to gather complex and broader data and go beyond what can be uncovered through questionnaires. It also enabled us to enquire deeply into the perceptions and opinions of the students about organizational culture in Turkish universities. In the same way, it provided insights if the dimensions of the questionnaire in the survey method were clear and understandable for the students.

The culture type is confirmed by asking the participants to describe the dimensions which represent their university. The questions in the interview are essentially the same or very similar to those in the OCAI. We triangulate this data to add the validity and clarity of OCAI survey findings and explore if the dimensions of the instrument were clear for the students, not to add a new data 
set. The interviews revealed that students were not aware of the third dimension-Management of employees. Due to its being from an employee's point of view and its irrelevance, this dimension was removed from the original six-dimensional questionnaire to prevent random or biased answers. Therefore, the modified OCAI questionnaire contained 5 dimensions and 4 statements, totalling 20 items.

\section{Sample}

In this study, the maximum variation sampling type is chosen from purposeful sampling methods. This type provides greater insights by looking from all angles to maximize -not generalize- the diversity relevant to the research questions (Yıldırım \& Şimşek, 2013). So, a total of 19 students from the second year to final year- participated in the interviews from the same universities mentioned above. Table 2 illustrates the demographic characteristics of the participants.

Table 2.

Distribution of students by independent variables

\begin{tabular}{lcc}
\hline \multicolumn{1}{c}{ Variables } & N(Participants) & $\%$ (Percentage) \\
\hline University & & \\
University 1 & 5 & 26 \\
University 2 & 4 & 21 \\
University 3 & 6 & 32 \\
University 4 & 4 & 21 \\
Gender & & \\
Female & 11 & 53 \\
Male & 8 & 42 \\
Year & & \\
Second & 3 & 17 \\
Third & 9 & 47 \\
Fourth & 7 & $\mathbf{1 0 0}$ \\
Total & $\mathbf{1 9}$ & 36 \\
\hline
\end{tabular}

\section{Data collection}

Interviews were conducted according to the participants' availability. Each interview session was completed in approximately 25-30 minutes. Students first answered the main questions and were able to refine the main questions, follow up questions have been delivered. In the interviews, both audio-recording and note-taking methods are used together.

\section{Data analysis}

Qualitative data were analysed with descriptive analysis and content analysis. In the descriptive analysis phase, the records have been deciphered by us and the field expert has drawn a correlation between audio recordings and written forms in one of the interviews. We sent the participants a copy of the written form with the aim of verifying the answers with them. The composed expressions were put into final form as indicated by the participants. 
In the content analysis phase, we read and classified the interview data and then tabulated it under the same theme, categories and codes. The direct quotations and opinions of the participants are provided to mirror the views of the participants.

\section{RESULTS RELATED TO RESEARCH QUESTIONS GAINED IN THE SURVEY}

RQ1: Student perceptions of the current organizational culture at public universities in Turkey

Table 3 contains the main results for the culture archetypes, geometric mean and 95\% CIs for mean and standard deviations for actual organizational culture type of all universities in the study.

As shown in Table 3, Hierarchical culture is the dominant culture type in the total sample. Students in Turkish universities perceive the current culture type as predominantly Hierarchy (gmean: 0.318), followed by Market (gmean: 0.288), Adhocracy (gmean: 0.202) and Clan (gmean: 0.190). Figure 2 illustrates the current organizational culture profile of public universities in Turkey. These results support the hypothesis of the study.

Table 3.

Culture archetypes of Turkish universities

\begin{tabular}{|c|c|c|c|c|c|c|c|c|}
\hline & \multicolumn{8}{|c|}{ Culture Archetypes } \\
\hline & Clan & & Adhocracy & & Marke & & Hierar & \\
\hline & Mean & $95 \% \mathrm{CI}$ & Mean & $95 \% \mathrm{CI}$ & Mean & $95 \% C I$ & Mean & $95 \% C I$ \\
\hline Overall & 0.190 & $\begin{array}{l}0.184- \\
0.196\end{array}$ & 0.202 & $\begin{array}{l}0.196- \\
0.208\end{array}$ & 0.288 & $\begin{array}{l}0.279- \\
0.295\end{array}$ & 0.318 & $\begin{array}{l}0.310- \\
0.328\end{array}$ \\
\hline
\end{tabular}

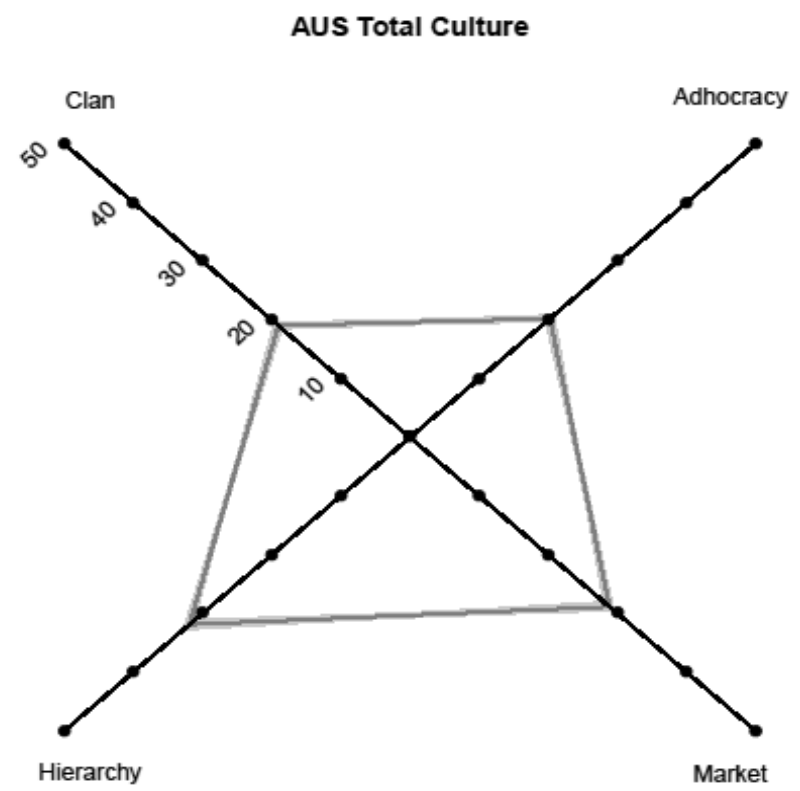

Figure 2.

OCAI total culture profile of Turkish universities 
RQ2: Student perceptions of the organizational culture dimensions at public universities in Turkey

Table 3 contains the main results for the culture archetypes, geometric mean and 95\% CIs for mean and standard deviations for organizational culture dimensions of all universities in the study. It also provides insight in the current organizational culture at Turkish universities. The most notable characteristics of the organizational culture at Turkish universities are measured on the five dimensions Dominant Characteristics, Organizational Leadership, Organizational Glue, Strategic Emphasis and Criteria of Success. The third dimension in OCAI- Management of Employees- was removed to prevent random or biased answers because it was not clearly comprehended by the students during the interviews. Therefore, the modified OCAI questionnaire contained 5 dimensions and 4 statements, totalling 20 items.

What is striking about this table is that the dominant culture type in two dimensions is different from the culture type in general. Market culture scores the highest results in dominant characteristics and criteria of success. Overall, these results support the hypothesis of the study and reveal the difference between the culture type in general and that in five dimensions.

Table 4.

Culture archetypes of Turkish Universities per dimension

\begin{tabular}{|c|c|c|c|c|c|c|c|c|}
\hline \multirow[t]{3}{*}{ Dimensions } & \multicolumn{8}{|c|}{ Culture Archetypes } \\
\hline & \multicolumn{2}{|c|}{ Clan } & \multicolumn{2}{|c|}{ Adhocracy } & \multicolumn{2}{|c|}{ Market } & \multicolumn{2}{|c|}{ Hierarchy } \\
\hline & Mean & $\begin{array}{l}95 \% \\
\mathrm{CI}\end{array}$ & Mean & $\begin{array}{l}95 \% \\
C I\end{array}$ & Mean & $\begin{array}{l}95 \% \\
C I\end{array}$ & Mean & $\begin{array}{l}95 \% \\
C I\end{array}$ \\
\hline $\begin{array}{l}\text { Dominant } \\
\text { Characteristics }\end{array}$ & 0.205 & $\begin{array}{l}0.193- \\
0.218\end{array}$ & 0.199 & $\begin{array}{l}0.187- \\
0.212\end{array}$ & 0.323 & $\begin{array}{l}0.307- \\
0.341\end{array}$ & 0.270 & 0.256 \\
\hline $\begin{array}{l}\text { Organizational } \\
\text { leadership }\end{array}$ & 0.188 & $\begin{array}{l}0.180- \\
0.198\end{array}$ & 0.213 & $\begin{array}{l}0.202- \\
0.223\end{array}$ & 0.248 & $\begin{array}{l}0.238- \\
0.260\end{array}$ & 0.348 & $\begin{array}{l}0.333- \\
0.364\end{array}$ \\
\hline Organization Glue & 0.181 & $\begin{array}{l}0.170- \\
0.191\end{array}$ & 0.195 & $\begin{array}{l}0.185- \\
0.207\end{array}$ & 0.279 & $\begin{array}{l}0.266- \\
0.294\end{array}$ & 0.344 & $\begin{array}{l}0.326- \\
0.360\end{array}$ \\
\hline Strategic Emphasis & 0.186 & $\begin{array}{l}0.178- \\
0.195\end{array}$ & 0.195 & $\begin{array}{l}0.186- \\
0.205\end{array}$ & 0.260 & $\begin{array}{l}0.248- \\
0.273\end{array}$ & 0.356 & $\begin{array}{l}0.341- \\
0.372\end{array}$ \\
\hline Success criteria & 0.186 & $\begin{array}{l}0.175- \\
0.197\end{array}$ & 0.202 & $\begin{array}{l}0.191- \\
0.214\end{array}$ & 0.332 & $\begin{array}{l}0.316- \\
0.348\end{array}$ & 0.278 & $\begin{array}{l}0.263- \\
0.293\end{array}$ \\
\hline
\end{tabular}

\section{RESULTS RELATED TO RESEARCH QUESTIONS GAINED IN INTERVIEWS}

Table 5 provides the overview of the interview findings obtained from the university students in Turkey. These seem to be consistent with the quantitative survey results. As revealed in the quantitative plotted survey data, students' qualitative responses also show that hierarchy characteristics are the 
dominant culture type in Turkish universities. Students highly emphasise control, efficiency, consistency and reliability in general (RQ1). Moreover, when we analyse each dimension specifically (RQ2), students perceive their universities' culture as hierarchical in organizational leadership and strategic emphasis. A participant described the hierarchical situation in organizational leadership as follows:

“(...) There's a distance from the university leaders, there's a hierarchy, it's hard to reach them. We only see them in and out of their rooms. They act according to the regulations; they do what their duties are...." (P7, U2, M, $2^{\text {nd }}$ year)

Another participant expressed her views in strategic emphasis as the following:

“(...) The education system is based on rote learning. Higher order thinking skills are not emphasised. Our professors don't use innovative teaching principles in lessons, but they say we should use them when we get to be teachers. The way to success is through regularity, stability and efficiency..." (P5, U1, F, $4^{\text {th }}$ year)

There is also a noticeable move towards the market culture in two dimensions - dominant characteristics and success criteria. This finding broadly supports the quantitative results in this study (RQ2). One participant remarked this situation in dominant characteristics as:

"(...) There is an interest-based relationship between friends. The dominance of competition reduces sharing and individuality. A result-oriented environment occurs..." (P1, U1, M, $3^{\text {rd }}$ year)

Commenting on market culture, one participant said for success criteria:

“(...) In fact, success at university should be measured according to continuous research, self-improvement and innovativeness, but unfortunately it is measured according to the exam results and GPA average. I think being a good teacher in the future does not mean getting high grades at university..." (P9, U3, M, $3^{\text {rd }}$ year)

The students perceive clan culture as dominant type in organizational glue which is different form quantitative result. A participant describes the organizational glue as follows:

“(...) After a difficult entrance exam, I settled in this department. I love my university and I feel happy and free. I belong here. Once again, I would choose the same department and the same university. Our teachers are very helpful warm and sincere and treat us like their colleagues., I learn a lot from them..." (P16, U4, $\mathrm{F}, 4^{\text {th }}$ year) 
Table 5.

Students' views on organizational culture in Turkish universities

\begin{tabular}{lllll}
\hline Themes & Categories emerged & $f^{*}$ & $\%$ & Most frequent codes \\
\hline Overall culture type & Clan culture & 37 & 20.3 & Commitment \\
& Adhocracy culture & 20 & 11 & Innovative outputs \\
& Market culture & 61 & 33.6 & Market share \\
& Hierarchy culture & 64 & 35.1 & Control \\
Dominant & Clan culture & 9 & 23.1 & Very personal place \\
characteristics & Adhocracy culture & 4 & 10.2 & Dynamic \\
& Market culture & 15 & 38.5 & Result oriented \\
Organizational & Hierarchy culture & 11 & 28.2 & Formal procedures \\
leadership & Clan culture & 9 & 24.3 & Mentoring \\
& Adhocracy culture & 3 & 8.1 & Innovation \\
& Market culture & 11 & 29.7 & result-oriented \\
Organizational glue & Hierarchy culture & 14 & 37.9 & Coordinating \\
& Clan culture & 14 & 38.9 & Loyalty \\
& Adhocracy culture & 4 & 11.1 & Innovation \\
& Market culture & 7 & 19.4 & Goal accomplishment \\
& Hierarchy culture & 11 & 30.6 & Formal rules, policies \\
Strategic emphasis & Clan culture & 3 & 9.1 & High trust, openness \\
& Adhocracy culture & 7 & 21.2 & New things \\
& Market culture & 8 & 24.2 & Competitive actions \\
& Hierarchy culture & 15 & 45.5 & Stability \\
& Clan culture & 2 & 5.4 & Human resources \\
& Adhocracy culture & 2 & 5.4 & Unique products \\
& Market culture & 20 & 54.1 & Winning \\
& Hierarchy culture & 13 & 35.1 & Efficiency
\end{tabular}

* Each participant presented their views on more than one category.

\section{DISCUSSION}

The present study was designed to describe the perceptions of students about the organizational culture of universities in Turkey using the OCAI. The variety of findings through survey and interviews revealed and validated the organizational culture type in universities. We discuss these findings in two aspects.

Firstly, the present study suggests that the dominant culture type of Turkish universities as perceived by students is hierarchical. It is probable that the national cultural structure of the Turkish society is a reason for this finding. As Geert Hofstede and Gert Jan Hofstede (2005) point out in their major study of Cultures and Organization, Turkey has a hierarchical workplace attri- 
buting control, order, authority, and smooth functioning. This finding is also consistent with the previous studies which have been carried out in Turkey (Açıkgöz, 2006; Bayazıt \& Koçaş, 2012; Beytekin et al., 2010; Caliskan \& Zhu, 2017; Halis, 2001; Sezgin, 2009). The findings of this research both from survey and interview provide insights that hierarchy culture is still the common culture in higher education institutions. Based on this data, we can infer that OCAI provides both a deeper understanding of the cultural composition and a map of the dominant and complementary culture type in an organization (Roman-Velazquez, 2005).

Hierarchy culture is mainly centered upon order, bureaucracy, top-down control and stability. Adherence to identified best practices, controlled processes and considerable oversight is seen as critical to productivity and success. It tends to be very conservative and be closed to innovation.

Following a hierarchy culture, students link their current culture with market culture. This culture type is the second highest culture in the current study which means these universities emphasise gaining accomplishment, goal-oriented activities and long-term plans being competitive.

By moving away from hierarchy and market culture, students hold their perceptions in the clan and adhocracy culture respectively. In the clan culture, the organization is just a personal place like an extended family. People are inclined to share a lot about themselves. Within this culture, the main focuses are on teamwork, consensus, loyalty, and participation.

Secondly, concerning the organizational culture type per dimension in OCAI, students put emphasis on hierarchy culture, market culture and clan culture. According to these data, we can infer that hierarchy culture became dominant in the aspects- organizational leadership, and strategic emphasis. Based on these results, the leaders can be exemplified as organisers and coordinators, and the universities emphasise stability, efficiency and process control. A possible explanation for this might be that the universities in this study are public ones which are governed and financed in accordance with the rules, policies and procedures defined by the government. Besides, market culture obviously seems to be the dominant culture type on the dimensions-dominant characteristics and criteria of success. These findings indicate that universities are dominantly characterised by a result-oriented environment that highlights getting things done and success is defined based on specific goals, reputation and success parameters. It seems possible that these results are due to the achievement and result oriented and competitive advantage strategy in the competitive environment of the universities. The market culture and hierarchy culture associate at the point of order and control (Cameron and Quinn, 2011). Considering this common aspect, Turkish public universities reflect mechanical processes with a controlled and result-oriented structure. These results corroborate the findings of a great deal of the previous works (Aktan \& Aydintan, 2016; Çavuşoğlu \& Köse, 2016; Erdem et al., 2010; Köse, 2017).

In the interviews, one dimension of organizational culture-organization glue - displayed a distinctive profile from the overall culture profile exhibited by 
Turkish universities regarding students' perceptions. Clan culture is the dominant culture type in organizational glue. This is also different from the quantitative data. It can be explained by the difficulties in entering higher education in Turkey and effects of organizational, individual and social factors (Bülbül, 2012). Thus, after entering the university, students in the faculty of education interiorise their universities, see themselves as part of the institution. As a result, they would like to take advantage of the availability of job opportunities after graduation, which is also supported by the other scholars (Aypay, Çekiç \& Boyac1, 2012; Kasalak, Özcan \& Dağyar, 2019). This data must be interpreted with caution because a clan culture is internally focused and integrated. It may reduce the organization discovering new ideas and opportunities in spite of being a flexibility dimension (Naranjo-Valencia, Jimenez-Jimenez \& SanzValle, 2016; Wolpert, 2002). Rohit Deshpande, John U. Farley and Frederick E. Webster (1993) further stated that the clan culture followed by hierarchy culture is associated with poor performance because they are internally focused.

Controlled by authorities, the university can never be more than what Stanley Aronowitz (2000) termed a knowledge factory, offering some academic training, but never producing new visions, new knowledge and new society. In the modern era with the development of alternative management theories, it has been substantially criticised as being a controlled structure overriding effectiveness and weakening the organization (Mintzberg, 1996). Returning briefly to the result of the study with Alvin Toffler's (1980) third wave theory, and the Turkish universities reflect the features of an industrial period in which hierarchy, control, rules, competition and goal accomplishment dominate.

\section{CONTRIBUTIONS, IMPLICATIONS, METHODOLOGICAL REMARKS, LIMITATIONS AND FUTURE RESEARCH}

The present study makes several noteworthy contributions to the current literature. Firstly, it is helpful to identify the dominant organizational culture type in Turkish universities according to the perceptions of students. Secondly, the results can give insights about the ways of being successful. Because, knowing the prevalent culture type in a university provides a better knowledge about how to be more effective, productive and innovative. Thirdly, by identifying the organizational culture type, it would be possible to diagnose problems and even to design and develop better structures or solutions which can affect the cultures.

The current research is the first empirical study to examine the perceptions of university students regarding organizational culture type using the instrument OCAI in Turkey. This study represents a step on the way to understand how university students see the cultural side of their universities and what features are clear or not. The findings may help the university leaders and teachers understand the students' thoughts in a better way in terms of culture type and provide them with information about student satisfaction and per- 
ceptions. This study is important as it uses the combination of qualitative and quantitative methods based on OCAI, which has not previously been reported in the literature. These findings can allow a starting point towards developing guidelines for shaping universities' organizational culture.

In the literature, there are two versions of the instrument, OCAI, which are Likert scales and ipsative scales. The Likert type of OCAI is generally used since it can report valid and reliable results (Bartram, 1996; Beytekin et al., 2010; Closs, 1996; Cornwell \& Dunlap, 1994; Di Stefano \& Scrima, 2016; Lamond, 2003). In many articles, unfortunately, the ipsative measures have not been considered reliable as they could yield statistical bias in restricted contexts (Closs, 1996; Cornwell \& Dunlap, 1994; Hicks, 1970; Johnson, Wood \& Blinkhorn, 1988).

However, our study is a pioneer in using ipsative version with the alternative analysis approach (ipsative measurement) provided by Prof. F. Eijnatten, et al (2015). This approach can control the social desirability bias, halo effects, and self-imposed responding (Cheung, 2006). It can also compute and compare the organizational culture type within the same organization while meeting three basic statistical requirements: scale invariance, permutation invariance and sub-compositional coherence (Aitchison, 1986; Amintoosi \& Kanhere, 2013; Eijnatten et al., 2015). So, it correctly captures the insider perceptions of the participants with respect to the organizational culture profiles.

Besides these advantages and implications, a few limitations need to be noted. Firstly, although there are sufficient student samples in this study, it is limited in terms of all stakeholders' perceptions. Future studies can compare experiences and perceptions of individuals within all departmental faculties, staff and administrators. It would be of great help in surveying the perceptions of more faculty members in all universities in the ranking list to get a broader aspect of organizational culture type. Secondly, we examined the current organizational culture type in 4 public universities. However, further studies could also be conducted to identify the current and preferred organizational culture types both in private and public universities which have different structures. Thirdly, we applied ipsative measurement in our study. Likerttype scales can be used because there is abundant room for further progress in quantifying results and obtaining the perceptions. Moreover, data can be analysed to test for systematic bias in the scores associated with the ipsative and Likert response formats.

In conclusion, based on student perceptions, this study can provide policy makers, academic leaders, academic staff and employees in administrative units with a broader knowledge of the current organizational culture types in universities in Turkey and identify the strengths and weaknesses of organizational culture in universities and to improve the quality, structures or practices through making innovations. 


\section{ACKNOWLEDGMENTS}

We would like to thank Dr. Frans M. van Eijnatten (Eindhoven University of Technology, Netherlands) for his methodological support in the study.

\section{REFERENCES}

1. Açıkgöz, B. (2006). Rekabetçi değerler yaklasımı açısından yöneticilerin örgüt kültürüne ilişkin algılamalan, Zonguldak Karaelmas Üniversitesi örneği (Unpublished master's thesis). Zonguldak: Karaelmas Üniversitesi.

2. Aitchison, J. (1986). The statistical analysis of compositional data. London, UK: Chapman and Hall.

3. Aktan, E. \& Aydintan, B. (2016). The Relationship between Organizational Culture and the Perception of Information Security on the Axis of Cameron-Freeman Organizational Culture Types: An Application in Government Universities. İşletme Araştırmalarn Dergisi (Journal of Business Research), 8/4, 324-344.

4. Amintoosi., H. \& Kanhere, S. (2013). Privacy-aware trust-based recruitment in social participatory sensing. In: Ivan Stojmenovic, Zixue Cheng, Song Guo (Eds.), Mobile and ubiquitous systems: computing, networking, and services (pp. 262-276), 10th International Conference. Japan: MOBIQUITOUS.

5. Argon, T. \& Kösterelioğlu, M. A. (2009). The university students' perception of faculty culture and the quality of life. Electronic Journal of Social Sciences, 8, 30, 043-061.

6. Aronowitz, S. (2000). The knowledge factory: Dismantling the corporate university and creating true higher learning. Boston: Beacon.

7. Aypay, A., Çekiç, O., \& Boyaci, A. (2012). Student retention in higher education in Turkey: A qualitative study. Journal of College Student Retention: Research, Theory E Practice, 14(1), 91-116.

8. Bartell, M. (2003). Internationalization of universities: A university culture-based framework. Higher Education, 45, 43-70.

9. Bartram, D. (1996). The relationship between ipsatized and normative measures of personality. Journal of Occupational and Organizational Psychology, 69, 25-39.

10. Bayazıt, M. \& Koçaş, C. (2010). Örgütsel kültür ve pazar odaklılık performansı: Kültür tipi ve "güçlü kültür" önermelerinin Türkiye' de testi. Yönetim Araştırmaları Dergisi, 10, 1-2, 35-70.

11. Becher, T. (1989). Academic tribes and territories: Intellectual enquiry and the cultures of disciplines. Buckingham: Open University Press.

12. Bektaş, F. (2010). Örgütsel imaj ve örgüt kültürü: Öğretmen adayı örnekleminde nedensel bir araştırma. Ĕ̆itim ve İnsani Bilimler Dergisi/Teori ve Uygulama, 1, 5-18.

13. Beyer, J. \& Nino, D. (2001). Culture as a source, expression, reinforcer of emotions in organizations. In: R. L. Payne, C. L. Cooper (Eds.), Emotions at work. Theory, research and applications in management (pp. 173-197). Chichester: John Wiley \& Sons.

14. Beytekin, O. F., Yalçınkaya, M., Doğan, M. \& Karakoç, N. (2010). The organizational culture at the university. International Journal of Educational Research Association, 2(1), 1-13.

15. Bryman, A. (2016). Social research methods. Oxford: Oxford University Press.

16. Bülbül, T. (2012). Dropout in higher education: Reasons and solutions. Ĕgitim ve Bilim (Education and Science), 37, 166, 219-235.

17. Cacciattolo, K. (2014). Understanding organisational cultures. European Scientific Journal [ESJ], 2, 1-7.

18. Caliskan, A. \& Zhu, C. (2017). The Impact of bureaucratic culture on educational innovations in higher education: Views of Turkish Academicians. In Arslan, H., Icbay, M. A., Duse, C. S. (Eds) Research on Education (pp. 55-63). Poland: Bialystok.

19. Cameron, K.S. \& Freeman, S. J. (1991). Cultural congruence, strength and type: relationships to effectiveness. Research in Organizational Change and Development, 5, 23-58.

20. Cameron, K. S. \& Quinn, R. E. (2011). Diagnosing and changing organizational culture: Based on the Competing Values Framework. ( $\left.3^{\text {rd }} \mathrm{Ed}\right)$. San Francisco: Jossey-Bass.

21. Cattell, R. B. (1944). Psychological measurement: ipsative, normative, and interactive. Psychol. Rev., 51(5), 293-303. 
22. Cheung, M. W. L. (2006). Recovering pre-ipsative information from additive ipsatized data: A factor score approach. Educ. Psychol. Meas., 66(4), 565-588.

23. Closs, S. J. (1996). On the factoring and interpretation of ipsative data. Journal of Occupational and Organizational Psychology, 69,4, 1-47.

24. Cohen, E. (2001). Globalization and the boundaries of the State: A Framework for analyzing the changing Practice of Sovereignty. Governance, 14(1), 75-97.

25. Collis, J., \& Hussey, R. (2009). Business research: A practical guide for undergraduate E postgraduate students. Basingstoke, Hampshire, UK: Palgrave Macmillan.

26. Cornwell, J. M. \& Dunlap, W. P. (1994). On the questionable soundness of factoring ipsative data: A response to Saville \& Willson. Journal of Occupational and Organizational Psychology, 67, 89-100.

27. Çavuşoğlu, S. \& Köse, S. (2016). Örgüt kültürünün örgütsel sessizlik davranışına etkisi. Dokuz Eylül Üniversitesi, Sosyal Bilimler Enstitüsü Dergisi, 18 (1), 115-146. doi: 10.16953/deusbed.46003

28. Deal, T. E. \& Kennedy, A. (1982). Corporate cultures. San Francisco: Jossey-Bass.

29. Deem, J. W., De Lotell, P. J. \& Kelly, K. (2015). The relationship of employee status to organizational culture and organizational effectiveness: A quantitative analysis. International Journal of Educational Management, 29(5), 563-581.

30. Denison, D. (1990). Corporate Culture and organizational effectiveness. New York: Wiley.

31. Denison, D. R. \& Mishra, A. K. (1995). Toward a theory of organizational culture and effectiveness. Organization Science, 6, 204 -223. doi:10.1287/orsc.6.2.204.

32. Deshpande, R. Farley, J. \& Webster, F. (1993). Corporate culture, customer orientation and innovativeness in Japanese firms: A quadrant analysis. Journal of Marketing, 57(1), 23-37.

33. Deshpande, R. \& Farley, J. U. (2004). Organizational culture, marketing orientation, innovativeness, and firm performance: An international research odyssey. International Journal of Research in Marketing, 21(1), 3-22.

34. Di Stefano, G. \& Scrima, F. (2016). The Psychometric Properties of the Italian Version of the Organizational Culture Assessment Instrument (OCAI). BPA-Applied Psychology Bulletin, 64 (276), 51-63.

35. Dill, D. D. (2014). Public policy design and university reform: Insights into academic change. Reforming Higher Education. Springer: Dordrecht.

36. Eijnatten, F., Ark, L. \& Holloway. S. (2015). Ipsative measurement and the analysis of organizational values: an alternative approach for data analysis. Qual, Quant, 49,559-579.

37. Erdem, F. \& İşbaşı, J. Ö. (2001). Eğitim kurumlarında örgüt kültürü ve öğrenci alt kültürünün alg1lamalar1. Akdeniz İ.̇.B.F. Dergisi. (1), 33- 57.

38. Erdem, R. (2007). Örgüt kültürü tipleri ile örgütsel bağl1lık arasındaki ilişki. Eskişehir Osmangazi Üniversitesi İIBF Dergisi, 2(2), 63-79.

39. Erdem, R., Adıgüzel, O. \& Kaya, A. (2010). Akademik personelin kurumlarına ilişkin algıladıkları ve tercih ettikleri örgüt kültürü tipleri. Erciyes Üniversitesi İktisadi Ve İdari Bilimler Fakültesi Dergisi, 36, 73-88.

40. Fjortoft, N., Smart, J.C. (1994). Enhancing organizational effectiveness: The importance of culture type and mission agreement. Higher Education, 27, 429-447.

41. Gayle, D. J., Tewarie, B. \& White, A. Q. (2003). Governance in the twenty-first century university: approaches to effective leadership and strategic management, ASHE. Annual Higher Education Report, 30, 1, 1-139.

42. Halis, M. (2001). Durumsallığı açısından Türk örgüt kültürlerindeki yönelimler - Ampirik bir çalısma. Yüzüncü Yıl Üniversitesi Sosyal Bilimler Enstitüsü Dergisi, 2, 109-135.

43. Handy, C. (1993). Understanding organizations. UK: Penguin Books.

44. Hicks, L.E. (1970). Some properties of ipsative, normative and forced-choice normative measures. Psychol. Bull., 74(3), 167-184.

45. Hill, F.M. (1995). Managing service quality in higher education: The role of the student as primary customer. Quality Assurance in Education, 3, 3, 10-21.

46. Hofstede, G. (2001). Cultures consequences: Comparing values, behaviours, institutions and organizations across nations. California: Thousand Oaks, Sage.

47. Hofstede, G. \& Hofstede, G.J. (2005). Cultures and organizations: Software of the mind (2 ${ }^{\text {nd }}$ Edition). New York: McGraw-Hill.

48. Howard, L. (1998). Validating the competing values model as a representation of organizational cultures. The International Journal of Organizational Analysis, 6(3), 231-250. 
49. İplikçi, F. N. \& Topsakal, Y. (2014). Üniversitelerde örgüt kültürünü belirleyen ve etkileyen boyutlar: Ampirik bir çalışma. Ç.Ü. Sosyal Bilimler Enstitüsü Dergisi, 23 (2), 47-60.

50. İra, N. (2011). Eğitim fakültelerinde örgütsel kültür ve yönetsel etkililik (Unpublished PhD Thesis). Dokuz Eylül Üniversitesi: İzmir.

51. Johnson, C., Wood, R., \& Blinkhorn, S. F. (1988). Spuriouser and spuriouser: The use of ipsative personality tests. Journal of Occupational Psychology, The British Psychological Society, 61, 2, $152-162$.

52. Kasalak, G., Özcan, M. \& Dağyar, M. (2019). Relationship between pre-service teachers' university image, perceptions and student loyalty: A structural equation model. Universal Journal of Educational Research, 7(2), 480-489.

53. Kesen, M. \& Akyüz, B. (2015). Üniversite örgüt kültürü algılamaları ve demografik değişkenlerin algılanan stresi yordayıcı değişkenler olarak incelenmesi. Çankır Karatekin Üniversitesi İ̈BF Dergisi, 5(1), 71-94.

54. Kezar, A. J. \& Eckel, P. D. (2002). The effect of institutional culture on change strategies in higher education: Universal principles or culturally responsive concepts. The Journal of Higher Education, 73, 435-460. doi:10.1353/jhe.2002.0038.

55. Kobylarek, A. (2017). Polish Humboldtian University in the face of paradigmatic change. UK: Cambridge Scholars Publishing.

56. Kotter, J. P. \& Heskett, J. L. (1992). Corporate culture and performance. New York, NY: Free Press.

57. Köse, M. F. (2017). Üniversitelerde örgüt kültürü ile akademik performans arasındaki ilişkiler (Unpublished PhD Thesis). Ankara: Gazi Üniversitesi Eğitim Bilimleri Enstitüsü.

58. Köksal, K. (2007). Yükseköğretimde örgüt kültürü ve alan araştırması (Unpublished master thesis). Balıkesir: Balıkesir University.

59. Kurgun, A. \& Bağıran, D. (2013). Rekabetçi değerler yaklaşımı ile örgütsel etkinliğin belirlenmesinde örgütsel sağlığın rolü: İzmir ili merkezindeki dört ve beş yıldızlı otel işletmelerinde bir araştırma. Dokuz Eylül Üniversitesi Sosyal Bilimler Enstitüsü Dergisi, 15(3), 477-510.

60. Kurt, T. (2015). Yükseköğretimin yönetiminde mütevelli heyetleri. Ankara: SETA.

61. Lacatus, M. L. (2013). Organizational culture in contemporary university. Procedia-Social and Behavioral Sciences, 76, 421-425.

62. Lamond, D. (2003). The value of Quinn's competing values model in an Australian context. Journal of Managerial Psychology, 18(1), 46-59.

63. Leland, S. M. (2002). Organizational culture: Understanding theoretical and practical applications. In Encyclopedia of life support systems: Public administration and public policy (Vol. 1, pp. 92-97). Paris, France: EOLSS Publishers.

64. Linnenluecke, M. \& Griffiths, A. (2010). Corporate sustainability and organizational culture. Journal of World Business, 45, (4), 357-366.

65. Meglino, B. \& Ravlin, E. (1998). Individual values in organizations: Concepts, controversies, and research. Journal of Management, 24, 3, 351-389.

66. Mintzberg, H. (1996). Musings on management. Harvard Business Review, 74, 61-67.

67. Murat, G. \& Açıkgöz, B. (2007). Yöeticilerin örgüt kültürü algılamalarına ilişkin bir analiz: Zonguldak Karaelmas Üniversitesi Örneği. Zonguldak Karaelmas Üniversitesi Sosyal Bilimler Dergisi, 3(5). 1-20.

68. Naranjo-Valencia, J. C., Jimenez-Jimenez, D. \& Sanz-Valle, R. (2016). Studying the links between organizational culture, innovation, and performance in Spanish companies. Revista latinoamaricana de Psicologia, 48(1), 30-41.

69. Ostroff, C., Kinicki, A. J. \& Tamkins, M. M. (2003). Organizational culture and climate. In: W. C. Borman, D. R. Ilgen, R. J. Klimoski, \& I. Weiner (Eds.), Handbook of psychology.Vol. 12 (pp. 565-593). Hoboken, NJ: Wiley.

70. Ouchi, W. G. (1980). Markets, bureaucracies, and clans. Administrative Science Quarterly, 25, 129-141.

71. Özcan, K., Çağlar, Ç., Karataş, İ. \& Polat, M. (2014). Administrators' power usage styles and their impact on the organizational culture in colleges of education: A case study. Educational Sciences: Theory \& Practice, 14(2), 560-569.

72. Özdevecioğlu, M. \& Akın, M. (2013). Yöneticilerin, Örgüt Kültürü ve Örgütlerarası Vatandaşlık Davranışları Algılamaları. Çankırı Karatekin Üniversitesi İktisadi ve İdari Bilimler Fakültesi Dergisi, 3(2), 112-131. 
73. Öztürk, Z., Şaklak, Ö. \& Yılmazer, Ö. (2010). Perceptions of Academic Staff About Organizational Culture in Universities, International Conference on New Trends in Education and Their Implications, 11-13 November 2010. Turkey: Antalya. ISBN: 9786053641049.

74. Quinn, R. E. \& Spreitzer, G. M. (1991). The Psyschometrics of the Competing Values Culture Instrument and an Analysis of the Impact of organizational Culture on Quality of Life, Bingley. UK: Emerald.

75. Ralston, D. A., Terpstra-Tong, J., Terpstra, R. H., Wang, X. \& Egri, C. (2006). Today's stateowned enterprises of China: are they dying dinosaurs or dynamic dynamos? Strategic Management Journal, 27(9), 825-843.

76. Ramachandran, S. D., Chong, S. C. \& Ismail, H. (2011). Organisational culture: An exploratory study comparing faculties' perspectives within public and private universities in Malaysia. The International Journal of Educational Management, 25(6), 615-634.

77. Roman-Velazquez, J. (2005). An empirical study of organizational culture types and their relationship with the success of a knowledge management system and the flow of knowledge in the U.S. government and nonprofit sectors. In: M. Stankosky (Ed.), Creating the discipline of knowledge management (pp.66-91). Oxford: Elsevier Butterworth-Heinemann. doi: 10.1016/ B978-0-7506-7878-0,50008-9.

78. Schein, E. H. (2010). Organizational Culture and Leadership (4 ${ }^{\text {th }}$ edition). San Francisco: Jossey-Bass.

79. Sezgin, O. (2009). Exploring the relationship between the concepts of organizational culture, organizational justice and organizational citizenship behavior (Unpublished Doctoral Thesis). Istanbul: Yeditepe University.

80. Simplicio, J. (2012). The university culture. Education, 133(2), 336-339.

81. Smart, J. C., Kuh, G. D. \& Tierney, W. G. (1997). The roles of institutional cultures and decision approaches in promoting organizational effectiveness in two-year colleges. The Journal of Higher Education, 68(3), 256-281.

82. Sporn, B. (1999). Towards more adaptive universities: Trends of institutional reform in Europe. Higher Education in Europe, 24(1), 23-33.

83. Tierney, W. G. (1988). Culture organizational in higher education. The Journal of Higher Education, 59(1), 2-21.

84. Toffler, A. (1980). The third wave. New York: Morrow.

85. Trompenaars, F. (1993). Riding the waves of culture: Understanding cultural diversity in business. London: Brealey.

86. Vasyakin, B. S., Ivleva, M. I., Pozharskaya, Y. L. \& Shcherbakova, O. I. (2016). A Study of the Organizational Culture at a Higher Education Institution Case Study: Plekhanov Russian University of Economics (PRUE). International Journal of Environmental and Science Education, 11(10), 11515-11528.

87. Wilderom, C. P. M., Glunk, U., \& Maslowski, R. (2000). Organizational culture as a predictor of organizational performance. In: N. M. Ashkanasy, C. P. Wilderom, \& M. F. Peterson (Eds.), Handbook of organisational culture and climate (pp. 193-209). Thousand Oaks, CA: Sage.

88. Wilkins, A. L. \& Ouchi, W. G. (1983). Efficient cultures: Exploring the relationship between culture and organisational performance. Administrative Science Quarterly, 28, 468 - 481. doi:10.2307/2392253.

89. Wolpert, J. D. (2002). Breaking out of the innovation box. Harvard Business Review, 80(8), 76-83.

90. Yaman, E. \& Ruçlar, K. (2014). Örgüt kültürünün yordayıcısı olarak üniversitelerde örgütsel sessizlik. Yükseköğretim ve Bilim Dergisi, 4(1), 36-50.

91. Yıldırım, A. \& Şimşek, H. (2013). Sosyal bilimlerde nitel araştırma yöntemleri (9 baskı). Ankara: Seçkin Yayıncılık.

92. Yılmaz, K. \& Oğuz, E. (2005). Faculty of educational sciences' students' perception of faculty culture. Ankara University, Journal of Faculty of Educational Sciences, 38, 1, 101-122.

93. YÖK. (2017). Higher Education System in Turkey. Retrieved from: https:/ /yok.gov.tr/ 